REVISTA DE LITERATURA E CULTURA RUSSA

\title{
Ostranenie: To Give Back the Sensation of Life
}

\section{Ostranênie: para devolver a sensação de vida}

Autor: Alexandra Berlina

Edição: RUS Vol. 11. № 16

Data: Setembro 2020 


\section{Ostranenie: To Give Back the Sensation of Life}

\section{Alexandra Berlina*}

\begin{abstract}
The present article studies Shklovsky's idea of emotional and cognitive renewal of the habitual - ostranenie - alongside cognate concepts in psychology and cognitive studies. It redefines ostranenie not as a device (as commonly accepted in literary studies), but as a cognitive/psychological effect, and suggests the term "extratextual ostranenie" to refer to the feeling one has when the usual becomes seemingly strange - and at the same time more rather than less emotionally relevant. As for literary ostranenie, even when it is created though characters who feel alienated or depersonalized, the readers' experience is exactly the opposite experience - emotional reconnection to the world.
\end{abstract}

Resumo: 0 presente artigo aborda a ideia de renovação cognitiva e emocional do habitual ostraniénie -, de Viktor Chklóvski, juntamente com conceitos semelhantes advindos da Psicologia e dos Estudos Cognitivos. 0 artigo redefine ostraniénie não como um procedimento (como normalmente aceito nos estudos literários), mas como um efeito cognitivo/ psicológico; também sugere a criação da expressão "ostraniénie extratextual" para se referir ao sentimento que se tem quando o usual se torna aparentemente estranho - e, ao mesmo tempo, mais ao invés de menos relevante emocionalmente. Quanto ao estranhamento (ostraniénie) literário, mesmo quando ele é produzido por meio de personagens que se sentem alienados ou despersonalizados, a experiência do leitor é exatamente o oposto da do personagem - o leitor vive uma reconexão emocional com o mundo.

Keywords: Shklovsky's Ostranenie; Comparative Literature; Cognitive Studies

Palavras-chave: Ostraniénie; de Chklóvski; Literatura comparada; Estudos cognitivos 


\section{Ostranenie: a Cognitive Refresher}

* Postdoc in comparative and Slavic studies, University of Erfurt. $\mathrm{PhD}$ in American Studies - University of Duisburg-Essen. Translator \& interpreter, Düsseldorf, Germany; alja.berlina@gmail.com
One hundred years ago, in 1917, a Russian literary scholar - or, rather, first-year-student - named Viktor Shklovsky published a paper entitled "Art as Device."1 Though the article is so old and its author was so young, the concept of making things strange that he called ostranenie might prove helpful to psychologists and cognitive scientists today. In fact, it is already doing so, but to a much lesser extent than it could, and often without any awareness of Shklovsky's work. Having first been mainly used in Slavic literary studies, ostranenie marched on, enriching the studies of different literatures, of cinema, and, to a lesser degree, of other arts. Its basis in human emotion and cognition makes it especially useful for comparative research, as it can be easily applied across disciplines and cultures. A stronger connection to the cognitive field would make the ostranenie even more productive. In the following, I will delineate the concept and propose an approach that could be useful in the study of human cognition and emotion (section 1). After alerting the reader to some terminological pitfalls (2), the article will deal with cognate concepts in psychology and cognitive studies (3).

Shklovsky's concept began as a psychological one: it was inspired by Lev Tolstoy's observation, made in the late 19th century, that habitual actions disappear from conscious memory. He cites Tolstoy: "I was dusting in the room; having come full circle, I approached the sofa and could not remember if I had dusted it off or not. I couldn't because these movements are routine and not conscious, and I felt I never could remember it". ${ }^{2}$ Instead of being glad to have so much head space cleared up for writing, Tolstoy was dismayed at the loss of reality induced by automatism: "if the whole life of many people is lived

1 The article was first translated into English as "Art as Technique"; this translation exhibits an array of misunderstandings. Presently, I used the title as translated by Sher (1991) and myself (Berlina 2016).

2 SHKLOVSKY, 2016b, pp. 80. 
unconsciously, it is as if this life had never been". ${ }^{3}$ Shklovsky proceeds: "Automatization eats up things, clothes, furniture, [your] wife and the fear of war..." To his mind, one of the crucial goals of art is to present things in unusual ways and thus to return them to consciousness, "to give back the sensation of life [...], to make the stone stony."4

Another source of the concept was a disagreement with the linguist Potebnya, a debate cognitivist in its nature. Potebnya's ideas actually had much in common with Shklovsky's own, first and foremost the attention toward the reader's mind (a rather novel approach in early 20th century Russia). In the somewhat simplified form in which Shklovsky understood Potebnya, the latter regarded mental economy as the crucial goal of literature, and images as an aid in processing information. As Shklovsky puts it, Potebnya and his followers claim that "imagery is intended to bring together heterogonous acts and objects, explaining the unknown via the known". ${ }^{5}$ The vehicle must thus be more familiar than the tenor.

Shklovsky sarcastically comments: "One might wonder how this law applies when Tyutchev compares summer lightning to deaf-mute demons, or when Gogol likens the sky to God's chasuble". ${ }^{6}$ He believed that fiction tended to make cognitive processes not easier and quicker, but more complex and prolonged - and thus potentially conscious. To give an example of ostranenie, a reference to "the incredible artificial weather that Earthlings sometimes create for other Earthlings when they don't want those other Earthlings to inhabit Earth any more"7 is more difficult to process than the word "bombing," and much less likely to be skimmed in semi-awareness world. ${ }^{8}$ To show that ostranenie is not restricted to literary fiction, let me give another example:

3 lbid.

4 lbid.

5 SHKLOVSKY, 2016b, pp. 73.

$6 \mathrm{lbid}$.

7 VONNEGUT, 1991, pp. 106

8 On religion and war made strange by Vonnegut, see: Berlina, 2017. 


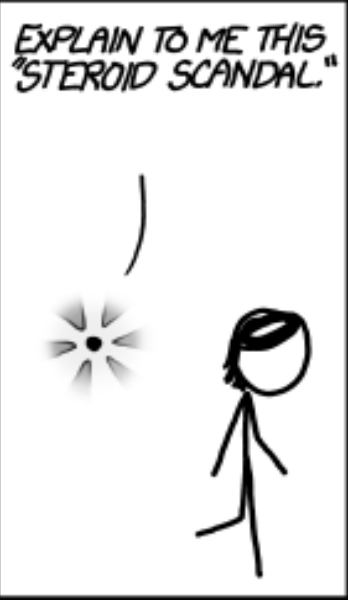

Randall Munro, https://xkcd. com/1173
WEUL, UH...

WE. HUMANS ARE SACKS OF CHEMICALS WHICH STAY ALIVE BY FINDING OTHER CHEMICALS AND PUTINIG THEM INSIDE US.

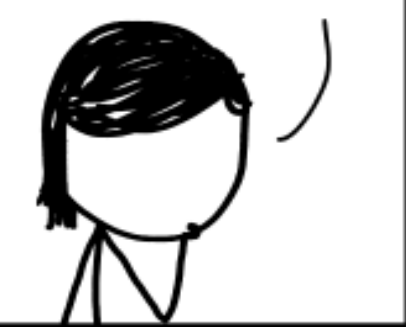

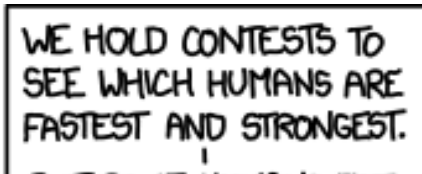

BUT SOME HUMANS EAT CHEMICALS THAT MAKE TTEM TOO FAST AND SIRONG.

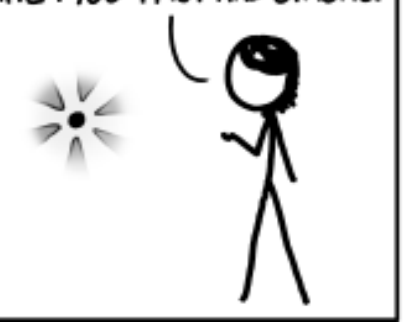

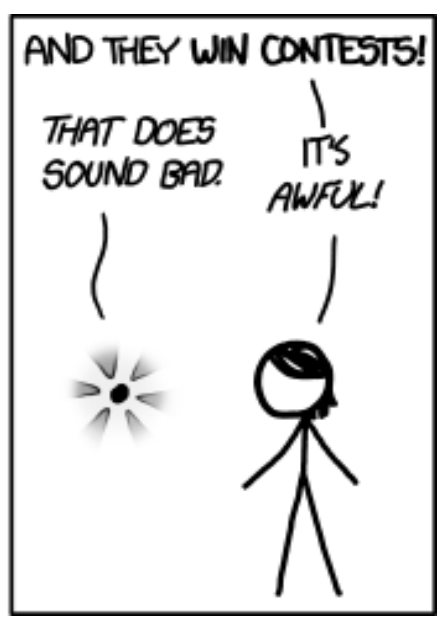

As these two examples show, ostranenie can be found in American science-fiction or in comic strips: the fact that the mechanism works the same way in these texts and in Russian classics cited by Shklovsky - while the objects of ostranenie differ culturally - makes it such an interesting concept for comparative review.

It must be said that the idea of deliberately making the habitual seem strange is much older than the concept of ostranenie: ${ }^{9}$ Aristotle believed that poetic language must be unusual, and the Romantics sought to "lift the veil from the hidden beauty of the world, and make familiar objects be as if they were not familiar" ${ }^{10}$ Less well-known than this Romantic attitude is the fact that scholars and philosophers such as Hume and Schlegel also believed that one of the goals of fiction was "rendering a familiar world from the perspective of an alien observer". ${ }^{11}$ Even before that, natural philosophers tried "to see the banal - for example a fly - as marvelous," for "only through deliberate self-estrangement could curiosity be inflamed and attention thereby heightened". ${ }^{12}$ Today, the capacity for childlike wonder is a cliché trait of the true scientist. 
If all this is so, what was special about Shklovsky's idea? Unlike the Romantics, Shklovsky saw art as a way to reawaken the mind not only to the beauty of the world but also to its horrors. Unlike Brecht, who went on to coin the concept of Verfremdung after Shklovsky and perhaps under his influence ${ }^{13}$ he did not believe that feelings should be restricted in order to promote critical thought. Indeed, he saw emotion and cognition as closely connected, prefiguring contemporary research. ${ }^{14}$

Shklovsky was keenly interested in the human mind and used evidence from psychology and neurology in his later work, "formalist" close readings going hand in hand with remarks such as "The human brain is a very strange construction. It knows more than it knows" ${ }^{15}$ The concept of ostranenie is his answer to the questions "Why do humans need fiction?" and "What does fiction do to our minds?" If Shklovsky lived today, he might well be termed a cognitivist.

Fifty years after the publication of "Art as Device", Shklovsky wrote (castigating himself, quite sincerely or not, for insufficient attention to the extratextual implications of ostranenie):

Let us look at mankind making its way toward comprehension, let us understand wherefore we change the world, how we comprehend and transform it, let us place art at the head of the human cognitive attack. [...] Thus, let us return ostranenie to its functional role. ${ }^{16}$

But what is the functional role of ostranenie? To answer this, we need to distinguish between different varieties. Shklovsky never does so explicitly, though he mentions several kinds. Jurij Striedter points out that ostranenie has two opposing functions: "to force a new way of seeing things upon the reader," but also "to steer perception toward the enstranging and complicating form itself." ${ }^{17}$ Another attempt to categorize ostrane-

13 Cf. GÜNTHER, 2001; MITCHELL, 1974.

14 Cf. e.g. STORBECK; CLORE, 2007.

15 SHKLOVSKY, 2016c, pp. 341.

16 SHKLOVSKY, 2016d, pp. 273-74.

17 STRIEDTER, 1969, pp. xxiii. 
nie was undertaken by Guy Cook, an applied linguist with a strong interest in cognitive science, who distinguishes "three areas of defamiliarization: sensory perception, text structure, and linguistic form"; 18 however, the ostranenie of many other elements - ideas, concepts, customs - seems to be missing here. Cook himself offers a better distinction when he speaks of "text schemata" vs. "world schemata" ${ }^{19}$ It is precisely these schemata that ostranenie disrupts, and thus it seems most profitable to unite Striedter's distinction with these terms and to differentiate between "ostranenie of the text" and "ostranenie of the world."

The former variety makes strange the very language, genre, or literary convention that it uses; the latter makes us "see the world with different eyes," as Shklovsky put it in one of his final articles, published when he was $90 .{ }^{20}$ "Ostranenie of the world" is the variety to which he seems to be ascribing the "functional role," and it is arguably the one which is of greater interest to the study of psychology and cognition. I also suggest redefining ostranenie not as a device (as commonly accepted in literary studies), but as a cognitive/psychological effect. This effect can be achieved by different devices, and it only makes sense to talk of ostranenie if it is experienced by the reader; the devices in the text are merely a prerequisite.

Moreover, I would like to point out that the feeling of wonder at the habitual can arise quite without art. It seems that there is no term exactly corresponding to it in psychology and cognitive science, though "schema disruption" and "dishabituation" come close (more on this in the following). I would like to suggest the term "extratextual ostranenie" ${ }^{21}$ to refer to the feeling one has when the usual becomes seemingly strange - and at the same time more rather than less emotionally relevant. Suddenly wondering about the weird practice of imbibing another animal's secretions (while drinking a habitual glass of milk), or becoming transfixed at the beauty of the human hand, or seeing one's partner as if for the first time while remaining aware of all the years together - all this is extrali-

21 "Text" in "extratextual" refers not only to texts proper, but also to films and other materials. 
terary ostranenie. Literally failing to recognize your boyfriend or to perceive him as familiar (as with amnesia or the Capgras syndrome respectively) is not an experience anybody should wish for. It is the tension between familiarity and perceived novelty that can make life feel more real.

\section{Terms and Confusions}

Should you decide to continue research on ostranenie, it's worth remembering that "Шкловский" is sometimes transliterated not as "Shklovsky", but as "Shklovskii" or "Šklovskij". However, this is nothing compared to the nomenclative adventures of his brainchild. Ostranenie is derived from the Russian strannyy (strange); it is missing a second " $n$ " due to young Shklovsky's orthographic idiosyncrasy. This article follows Viktor Shklovsky: A Readerin using the original term - for the sake of uniformity and clarity: the alternatives are many and ambiguous. So far, literary scholars and translators have used "making strange," "defamiliarization," "estrangement" and "enstrangement." This last version, coined by Benjamin Sher, might be the best solution, but it did not catch on - even scholars citing Sher tend to forget the " $n$ " (much like Shklovsky did).

"Estrangement" is associated with interpersonal estrangement and Marxist estrangement of the workers from their work; both suggest emotional disconnection and thus the very opposite of ostranenie. "Defamiliarization" is associated with a problematic translation. ${ }^{22}$ And as if all these variations were not enough, "foregrounding" is used almost synonymously, but usually only in regard to the ostranenie of the text. In short, there is enough room for confusion in the literary domain alone. ${ }^{23}$

Things become even more complicated when we approach the intersection of literary and cognitive studies. Some literary scholars speak of "cognitive estrangement," which sounds promising for the present purpose. However, this concept, 
which has been coined in science-fiction studies, ${ }^{24}$ is rather a jumble of Brecht's Verfremdung and ostranenie. ${ }^{25}$ Guy Cook, whose work will be discussed below, describes the function of ostranenie as "schema refreshment" - which sounds as if the schema itself was refreshed (made more salient) rather than challenged. But he also speaks of "schema disruption", ${ }^{26}$ which seems to me a better paraphrase for ostranenie. Bearing these difficulties in mind, let us now venture further afield.

\section{Ostranenie and its Cousins in Cognitive Psychology}

Often, suddenly experiencing the familiar as unfamiliar is a troubling sign. Accordingly, by far the most psychological research on such experiences deals with their problematic varieties. Imagine that your partner of many years suddenly seems unfamiliar to you. If you literally fail to recognize the person, this might be a case of amnesia. Or, more exotically, a stroke or a blow to your head might have induced prosopagnosia - "face blindness" - a cognitive disorder which makes you unable to recognize familiar faces (including your own), while your memory, thinking and sight remain intact. This would feel much like being Humpty Dumpty, who tells Alice he couldn't possibly recognize her if they met again: after all, she has a nose in the middle of her face, and a mouth above it, just like everyone else. If your partner feels unfamiliar even though you know who they are, you might be suffering from yet another unusual and grave condition, the Capgras syndrome: the delusion that a person close to you has been replaced by an impostor.

The doppelgänger - a character's look-alike, usually evil - might be a literary trace of the Capgras delusion and con-

24 SUVIN, 1979

25 Cf. SPIEGEL, 2008

26 COOK, 1994, pp. 191. 
nected disorders (sometimes even called the doppelgänger syndrome), described by writers such as E.T.A. Hoffmann and E. A. Poe more than a hundred years before the phenomenon caught the attention of psychology. The parallel to ostranenie is clear enough: you know that something is familiar, but you also feel that it isn't. But there is also a crucial difference. Suffering from the psychiatric disorders described above, you feel disconnected; experiencing ostranenie, you feel reconnected. The awareness of actual familiarity is as crucial as the feeling of novelty.

Dealing with faces and familiar people is just one particular field among many conditions in which reality is not emotionally recognized as such; the umbrella terms are "derealization" and "depersonalization". Again, both derealization and ostranenie can make strange the habitual, but ostranenie does so in an emotionally reconnective rather than disconnective way. (On another vector, ostranenie has an opposite that is worse still, namely total automatization, the absence of thought and feeling - in the final analysis, the absence of life.)

Considering this, it does not seem too strange that Tolstoy - the Russian master of ostranenie, the one who inspired Shklovsky to coin the concept - might have suffered from a missing feeling of reality. This is what Douglas Robinson argues in his recent book Estrangement and the Somatics of Literature. "Estrangement for Tolstoy," he writes, "was a debilitating psychological disorder-what the psychiatric community refers to as depersonalization" ${ }^{27}$ In as far as one can diagnose a dead man (mainly on the basis of his writing, and without formal training in psychology), there are good reasons to side with Robinson. However - even though opposite extremes can be close - subsuming the literary effect and the psychological problem under the same title is misleading. The writer might have felt disconnected, but what he created (perhaps partly as a form of self-medication) was reconnection. Literary characters, too, may feel depersonalized even while providing exactly the opposite experience to the reader. ${ }^{28}$ The intriguing question is: can ostranenie work therapeutically? How far does it reach out on the connection-disconnection continuum? It can 
pull you up from the middle ground, certainly, but how about the clinical cases of "derealization" and "depersonalization"?

There have, in fact, been some attempts (very few and very recent) to treat these conditions using methods that bear some resemblance to ostranenie: "mindfulness-based cognitive therapy" and, to a lesser degree, "schema therapy." Both are forms of treating psychiatric and psychological disorders developed at the end of the 20th century and showing a key similarity to ostranenie - though their developers never mention Shklovsky. The similarity consists in the belief that automatisms can be hurtful. This idea, of course, has a long history in psychology, from the Freudian exploration of the subconscious to various cognitive approaches (as pioneered by Beck, 1975) - but "mindfulness" and "schema therapy" are particularly close to Shklovsky's ideas.

Let us begin with the concept of or Mindfulness-Based Cognitive Therapy, MBCT for short (the term "deautomatization" is also occasionally used). This approach views awareness as the prerequisite of happiness and creativity. Practitioners such as Jon Kabat-Zinn and Ellen Langer argue that automatism is deadening to feelings and consciousness. The concept of mindfulness stresses the sense of concentrating on the present, consciously and non-judgmentally experiencing thoughts, feelings, and sensations. But while ostranenie can involve anything from your body to the most abstract ideas, mindfulness tends to deal with the immediate environment. What unites them is that both are methods of counteracting what Shklovsky calls "automatization" and what MBCT calls "mindlessness." Shklovsky, who disliked all things esoteric, would have criticized the New Age associations of the concept - still, there are clear parallels here.

The goal of ostranenie is to replace the automatic recognition of schemas with conscious experience ${ }^{29}$ Schemas are an

29 There is some evidence that schemas are re-created and changed every time they are activated, like memories. This makes the picture more complicated, but this outside of the present scope of study. 
integral component of our thinking, and it is only logical that by far the most psychological studies only discuss "cognitive schema disruption" in regard to traumatic experiences. As far as I could find, no concept of schema subversion or disruption in cognitive studies and psychology quite corresponds to ostranenie. There are, instead, several approaches which encapsulate different aspects of it. One of them is schema therapy (also known as SFT, schema-focused therapy). Developed by Jeffrey Young in the early 1990s, it was meant to help patients who suffered from personality disorders. The idea was to identify "negative schemas" of thought and to practice critical awareness of them.

SFT does not concern itself with the sense of novelty or wonder. Moreover, it radically differs from ostranenie by restricting the number of schemas to eighteen, all of them maladaptive and stemming from childhood experiences. ${ }^{30}$ Part of the therapy is "cognitive restructuring," which can involve attempts to see the situation from another perspective - potentially a form of ostranenie. But it only concerns a very restricted number of "maladaptive thought patterns" - a use far more restrictive even than "mindfulness," and immeasurably more restrictive than ostranenie. Besides, though Shklovsky does particularly abhor some automatized views (such as that killing is fine if your country tells you so), it is the automatization itself - rather than any particular content or "pattern" - that he finds most dangerous.

Considering the origin of the concept, it is no wonder that many psychological and cognitive approaches to it deal with language and literature. In the 1990s, while Young was working on schema therapy, the cognitive linguist Guy Cook developed another kind of schema theory in his book Discourse and Literature: the Interplay of Form and Mind - in this case, explicitly and effectively working with the concept of ostranenie (which he calls "defamiliarization"). Cook argues that any cognitive theory needs to take into account literary texts, as they "perform the important function of breaking down exis-

30 YOUNG, 1994. 
ting schemata, reorganizing them and building new ones". ${ }^{31}$ He is well aware, though, that ostranenie can also exist outside literature. Cook convincingly criticizes one of the shortcomings of formalism, namely that it presents "a theory of literature as deviation from a norm. Yet it fails to identify the norm by which this variation is defined" ${ }^{32}$ It is crucial to identify the changing norms and schemata (scripts, concepts) against which ostranenie works.

Discourse and Literature has built a robust bridge from Shklovsky to cognitive science. Unfortunately, far too few people use it. Those who do tend to be linguists, such as Elena Semino. She positions her approach as cognitive, ${ }^{33}$ and refers to a key text in psychology, Bartlett's Remembering, as the originator of the concept of schemata. Semino does not mention Shklovsky, but it is quite interesting that Bartlett's book, just like Tolstoy's diary entry that inspired "Art as Device," deals with the interaction of habit and memory. To use contemporary terms, automatization is essential for procedural (unconscious) memory, while ostranenie can help create declarative (conscious) memories. Viewed from this perspective, ostranenie might well prove to be a productive concept in memory studies.

Within literary studies, the first forays into ostranenie and empirical psychology/cognitive studies were undertaken in the 1980s (beginning with Peer, 1986). Soon, many empirical studies on "foregrounding" and related phenomena followed (to repeat, this term usually implies ostranenie of the text - arguably the variety that is less productive for cognitive psychology). The fact that "foregrounded" passages produce longer reading times and higher ratings of strikingness and affect ${ }^{34}$ may not be particularly surprising; still, there is perhaps more empirical reader-response research on ostranenie than on

31 COOK, 1994, pp. 10.

32 Ibid., pp. 138.

33 SEMINO, 1995, pp. 79.

34 E.g. HUNT; VIPOND, 1985; MIALL; KUIKEN, 1994; HANAUER, 1998; HAKEMULDER, 2010; AURACHER, 2007. 
any other literary effect. Moreover, it has been argued in addition that ostranenie enhances the cooperation of the brain hemispheres. ${ }^{35}$ Recently, research ${ }^{36}$ has shown how the brain reacts to "defamiliarization" (the preferred term in psychology, often used seemingly without awareness of Shklovsky's work). Another contemporary study ${ }^{37}$ found that people strongly underestimated their own pleasure in rediscovering ordinary, mundane (rather than extraordinary) experiences of their lives. Here, a trace of ostranenie was created simply by virtue of passing time.

A much-cited article published in Science in 2013 demonstrated a correlation between reading "literary fiction" and a better-developed theory of mind. Science is a renowned journal, and when I first saw the abstract, I thought a new era was coming for ostranenie: "defamiliarization" is cited as the defining feature of literariness used in setting up the research parameters. ${ }^{38}$ However, it turned out that the authors only appeared to be familiar with Shklovsky's concept second-hand. Accordingly, on the next page they describe the experiment as follows: "we selected literary works of fiction by award-winning or canonical writers and compared their effects on ToM with reading nonfiction, popular fiction, or nothing at all." The study does not even list the chosen texts, but it is safe to say that "award-winning and canonical writing" need not necessarily be conductive to ostranenie.

It is gratifying to see an empirical study confirm the thesis that fiction is a ToM-training tool, as it has been developed by cognitive literary scholars (such as Zunshine, 2006), but it would be premature to see the study by Kidd and Castano as an indication that ostranenie specifically matters for ToM. Even if the study did use ostranenie-rich fiction, there would still be the matter of correlation and causation. As it is, all we can say is that the reading of fictional minds trains the rea-

35 ALEXANDROV, 2007, pp. 108-109.

36 BOHTN et al., 2012; DEK et al., 2015.

37 ZHANG et al., 2014.

38 KIDD; CASTANO, 2013, pp. 377. 
ding of real minds (the mental process, after all, is much the same), and that the reading of particularly strange minds ostranenie often involves the perspectives of time and space travelers, animals, etc. - might well be a form of ToM exercise deserving further study.

An overview of empirical studies investigating the relationship between reading and empathy / ToM was published in $2015,{ }^{39}$ drawing on several earlier overviews but also adding new material and fundamental reflections. It would make no sense to sum up this detailed and readily accessible article here; one section (4.2.), though, deserves particular attention. Entitled "defamiliarization," it convincingly argues that ostranenie plays a crucial and underappreciated role in the discussion of empathy and fiction.

None of the empirical studies explicitly differentiate between ostranenie of the world and ostranenie of the text. When Koopman and Hakemulder write that "foregrounded features in the text (e. g., novel metaphors, rhyme) can lead to aesthetic feelings of perceived beauty, but particularly surprise and defamiliarization," ${ }^{40}$ they are talking about ostranenie of the text. They proceed with a graph that shows "foregrounding" as a source of self-reflection and, in a potential next step, self-awareness and self-change. However, it is actually ostranenie of the world that stands a much better chance to provoke self-reflection. It is not to be denied that encountering an unusual rhyme may lead to the conscious observation "well, this is an unusual rhyme!" and then perhaps to the awareness of one's own role as a reader. Still, surprised reflection about one's own life seems much more probable when encountering passages such as these, to quote some books published between 1623 and 2014 in different languages and countries and dealing with matters ranging from ships to mobile phones:

There they told me to enter a certain little cottage made of planks. It did not stand on the ground, nor was it based on a foundation, nor was it underpinned by braces, columns or

39 KOOPMAN; HAKEMULDER, 2015.

40 lbid., section 4.2 
supports. Rather, it rested on the water and wobbled to and fro $[. . .]^{41}$

I believe few people have thought much upon the strange multitude of little things necessary in the providing, producing, curing, dressing, making, and finishing this one article of bread. ${ }^{42}$

He looked at the approaching Frenchmen, and though but a moment before he had been galloping to get at them and hack them to pieces, their proximity now seemed so awful that he could not believe his eyes. "Who are they? Why are they running? Can they be coming at me? And why? To kill me? Me whom everyone is so fond of?"43

the fiddlers drew their rosined horse-hair across the stretched intestines of lambs ${ }^{44}$

I tend to think of human beings as huge, rubbery test tubes, too, with chemical reactions seething inside. ${ }^{45}$

Not too far above the steep canyons there had hung an imperial backdrop of calm, blue distance, in which extravagantly lovely white creatures - fat, sleepy things - hovered. ${ }^{46}$

I deliberately chose very different works to show what rich food ostranenie offers for comparatists. Let us look at the authors: Comenius was a 17th century Czech theologian; Defoe an English 18th century journalist; Tolstoy a 19th century Russian pacifist; Huxley a 20th century British intellectual; Vonnegut and Amis - American (and British-American) 20-21st century writers with an affinity for the fantastic.

All of them create ostranenie thus disproving the suggestion famously made by Hansen-Löve ${ }^{47}$ that it appears almost exclusively in works of the Russian avantgarde - but their goals and/or the readers' reactions may well different. For

41 COMENIUS, 1998 [1623], pp. 88.

42 DEFOE, 2003 [1719], pp. 94.

43 TOLSTOY, 2016 [1869], chapter XIX, final paragraph.

44 HUXLEY, 2009 [1928], pp. 31.

45 VONNEGUT, 2010 [1973], pp. 4.

46 AMIS, 1994 [1981], pp. 17.

47 HANSEN-LÖVE, 1978, pp. 21. 
instance, both Comenius and Defoe express wonder at human creations - ships and bread respectively. However, when a Christian philosopher talks about the insecure footing of a sea voyager, one is tempted to read this as a metaphor for earthly life, while Defoe's admiration of the achievement that is baked bread appears to be straightforward. After all, he was a pioneer of economic journalism; in fact, his enumeration is reminiscent of Leonard Read's seminal essay "I, Pencil" published 230 years later and enumerating the complexities of producing an object as simple as a pencil.

The two writers' devices, too, are different in this case. Comenius describes the ship without naming it, as if he had no word for it. The narrative is autobiographical; he had indeed never seen a ship before - still, the device is used consciously: he could have said "ship," but by refraining from doing so he forces readers to engage in a bottom-up cognitive process (reconstruction) instead of a top-down one (recognition). Defoe's Robinson Crusoe verbalizes and shares his sense of wonder and enumerates that which usually goes unmentioned. Ultimately, the two passages' long-term effect on the reader may be similar: finding myself eating a bagel in an airport, I might find myself newly grateful for the marvel of bread and wondering what Comenius, with his amazement at ships, would have to say about airplanes. When such different devices can work in such similar ways, it does indeed appear to make sense to regard ostranenie as an effect (rather than a particular device.)

So far, we have looked at the techniques and effects of ostranenie. What about its objects? They, too, can differ vastly. In the first two examples, we are dealing with man-made things; Huxley, too, can be said to talk about violins - but arguably the ultimate object is "music." Tolstoy's object is "war" - or "killing people". Vonnegut describes the human organism, Amis - clouds. I only selected examples that make strange the outside world rather than the text itself: firstly, because I feel the latter variety (aka "foregrounding") is overrepresented in research, and secondly, because the former one (that I call "ostranenie of the world") is a more promising field for cognitive 
comparative studies.

Like Tolstoy - Shklovsky's primary example - Vonnegut and Amis are particularly prone to make strange the world. It is perhaps not a matter of chance that Vonnegut is associated with science fiction, and Amis with "Martian poetry," a movement whose main goal was showing things as strange, as if through a space alien's eyes. In his "Taxonomy of the Emotions of Literary Response," the cognitive psychologist Keith Oatley goes as far as calling ostranenie "The Amis Effect". ${ }^{48}$ Citing phrases from Amis' Money such as the zeugma "This restaurant serves no drink, this one serves no meat, this one serves no homosexuals",49 Oatley observes the "incongruous juxtapositions which do not allow easy assimilation of this material to a schema." ${ }^{50}$ Again, the examples provided - such as the one above - mostly feature the ostranenie of text and language: it is not so much the restaurant business that is being de-automatized here as the verb "serve." However, such juxtapositions can also function to make strange the world. Often used in jokes, they are connected to the cognitive concepts of "bisociation"51 and "conceptual blending"; 52 studying the connections between conceptual blending and ostranenie could be a worthwhile endeavor. Oatley concludes that "literary simulation, which runs on minds rather than on computers" might be just as useful to cognitive science as computer simulation..$^{53}$ Ostranenie, then, could turn out to be a particularly productive piece of software.

Apart from "the Amis effect" (admittedly a tongue-in-cheek nickname rather than a seriously suggested term), Oatley calls ostranenie "dishabituation" (passim), which brings us to yet another term in cognitive psychology. "Dishabituation" refers to "a change in a familiar stimulus that prompts us to start no-

48 OATLEY, 1995, pp. 58.

49 AMIS, 1985, pp. 168.

50 OATLEY, 1995, pp. 59.

51 KOESTLER, 1964.

52 FAUCONNIER; TURNER, 2008.

53 OATLEY, 1995, pp. 72. 
ticing the stimulus again". ${ }^{54}$ The textbook just cited proceeds to explain that habituation (automatization) is a necessary cognitive mechanism, but that it also can lead to slips and inattentiveness; ${ }^{55}$ in such cases, dishabituation can be helpful. The book addresses students, and Sternberg suggests that it might combat boredom during a lecture: "Try noticing other aspects of your instructor, like hand gestures or body movements, while still paying attention to the content.".56 Imagine a film showing the lecturer's hand or mouth in close-up while he or she talks: this shift of attention is bordering on the surreal, and on ostranenie. A 2014 article on dishabituation concludes that its "magnitude determined by the current arousal level" ${ }^{57}$ It is, then, connected to emotion, as is ostranenie.

Does all this mean that "dishabituation" is the cognitive term for ostranenie? Not quite. Firstly, it is mostly studied in regard to processes and tasks, rather than concepts and ideas, "things, clothes, furniture, your wife and the fear of war" (to return to that famous Shklovskyan phrase) - and often it is defined as concerning only the most elementary, unconditioned responses, such as a dog salivating at the smell of food (rather than the ring of a bell). Secondly, the general view is that both habituation and dishabituation "occur automatically" and "require no conscious effort" ${ }^{\prime \prime}{ }^{58}$ Thirdly, dishabituation is a matter of renewing responses (emotional at most, often purely physiological), hardly ever a matter of cognition.

"Disinhibition" and "sensitization" are not the same as ostranenie, either. There seems, then, to be no exact equivalent of ostranenie in psychology or cognitive studies.

As a different scholar whose name also happens to be Ster-

54 STERNBERG, R., 2008, pp. 532.

55 Ibid., pp. 73.

56 lbid., pp. 74.

57 STEINER; BARRY, 2014, pp. 79.

58 STERNBERG, R., 2008, pp. 72. However, Sternberg's own lecture example does depict a conscious effort, and it seems worthwhile to study such efforts - leaps of imagination, cognitive frame shifts - as they take place when reading, watching a film or simply consciously taking a new look at life. 
nberg recently observed, "from an interdisciplinary view, [ostranenie] offers an attractive meeting ground". ${ }^{59}$ While he is talking about different schools of literary study, what he says also holds true for comparative approaches, as well as for the study of the human mind. The ways literature (as well as films and other cultural projects from songs to comic strips) helps to experiencing the familiar afresh is especially intriguing in comparatist terms: the effect combines a seemingly universal cognitive background with a great deal of cultural variety.

\section{References}

ALEXANDROV, Vladimir. "Literature, Literariness, and the Brain." Comparative Literature, vol. 59, no. 2 (Spring, 2007), pp. 97-118.

AMIS, Martin. Money. London: Penguin, 1985.

AMIS, Martin. Other People. New York: Vintage, 1994.

AURACHER, Jan. “... Wie Auf Den Allmächtigen Schlag Einer Magischen Rute": Psychophysiologische Messungen Zur Textwirkung. Baden-Baden: Dt. Wissenschafts-Verlag, 2007.

BAMELIS, Lotte L M, Silvia M A A Evers, Philip Spinhoven, and Arnoud Arntz. "Results of a Multicenter Randomized Controlled Trial of the Clinical Effectiveness of Schema Therapy for Personality Disorders." The American Journal of Psychiatry, vol. 171 (3), American Psychiatric Association, 2014, pp. 305322.

BECK, Aaron T. Cognitive Therapy and the Emotional Disorders. Madison: International Universities Press, 1975.

BERLINA, Alexandra. Viktor Shklovsky: A Reader. New York: Bloomsbury. 2015, ed. 2016.

BERLINA, Alexandra. "Translating 'Art, as Device."' Poetics Today, vol. 36 (3), 2015, pp. 151-56.

BERLINA, Alexandra. "Religion and War Made Strange: Ostra- 
nenie in Vonnegut's Slaughterhouse-Five." Amerikastudien / American Studies, vol. 62 (1): forthcoming, 2017.

BOHRN, Isabel et al. "Old Proverbs in New Skins: An FMRI Study on Defamiliarization." Frontiers in Psychology, vol. 3, 2012, $204 \mathrm{pp}$.

COLMAN, Andrew M. Oxford Dictionary of Psychology. Oxford: Oxford University Press, 2008.

COMENIUS, Johann Amos. The Labyrinth of the World and the Paradise of the Heart. Translated by Howard Louthan and Andrea Sterk. Costa Mesa: Paulist Press, 1998.

COOK, Guy. Discourse and Literature: The Interplay of Form and Mind. Oxford University Press, 1994.

DASTON, Lorraine J.; PARK, Katharine. Wonders and the Order of Nature, 1150-1750. New York: Zone Books, 2001.

DEFOE, Daniel. Robinson Crusoe. London: Penguin, 2003.

DEK, Eliane et al. "Perseveration Causes Automatization of Checking Behavior in Obsessive-Compulsive Disorder." Behaviour Research and Therapy, vol. 71, 2015, pp. 1-9.

DUHIGG, Charles. The Power of Habit: Why We Do What We Do in Life and Business. New York: Random House, 2012.

FAUCONNIER, Gilles; TURNER, Mark. The Way We Think: Conceptual Blending and the Mind's Hidden Complexities. New York: Basic Books, 2008.

GINZBURG, Carlo. 1996. "Making Things Strange: The Prehistory of a Literary Device." Representations, no. 56, pp. 8-28.

GÜNTHER, Hans. "Verfremdung: Brecht Und Šklovskij." In: Gedächtnis Und Phantasma. Festschrift Für Renate Lachmann., edited by Susi K. Frank, Erika Greber, Schamma Schahadat, and Igor Smirnov. München: Kubon \& Sagner, 2001, pp. 137-45.

HAKEMULDER, Jemeljan F. "Foregrounding and Its Effect on Readers' Perception." Discourse Processes, v. 38 (2). Lawrence Erlbaum Associates, Inc., 2010, pp. 193-218.

HANAUER, David. "The Genre-Specific Hypothesis of Reading: Reading Poetry and Encyclopedic Items." Poetics, vol. 26 (2), 1998, pp. 63-80. 
HANSEN-LÖVE, Aage A. Der russische Formalismus. Wien: Verlag der Österreichischen Akademie der Wissenschaften, 1978.

HUNT, Russell, and Douglas VIPOND. "Hunt, Russell/Douglas Vipond, Crash-Testing a Transactional Model of Literary Reading." Reader: Essays in Reader-Oriented Theory, Criticism, and Pedagogy, vol. 14, 1985, pp. 23-39.

HUXLEY, Aldous. Point Counter Point. London: Random House, 2009.

KAREEM, Sarah Tindal. Eighteenth-Century Fiction and the Reinvention of Wonder. Oxford: Oxford University Press, 2014.

KIDD, David C.; CASTANO, Emanuele. "Reading Literary Fiction Improves Theory of Mind." Science (New York, N.Y.) vol. 342 (6156), 2013, pp. 377-80.

KOESTLER, Arthur. The Act of Creation. Arkana, 1964.

KOOPMAN, Eva M.; HAKEMULDER, Frank. "Effects of Literature on Empathy and Self-Reflection: A Theoretical-Empirical Framework." Journal of Literary Theory, vol. 9 (1), 2015, 79-111. KUMAGAI, Arno, WEAR, Delese. "'Making Strange': A Role for the Humanities in Medical Education." Academic Medicine, vol. 89 (7), 2014, pp. 973-977.

KUYKEN, Willem et al. "Effectiveness and Cost-Effectiveness of Mindfulness-Based Cognitive Therapy Compared with Maintenance Antidepressant Treatment in the Prevention of Depressive Relapse or Recurrence (PREVENT): A Randomised Controlled Trial." The Lancet, vol. 386 (9988), 2015, pp. 63-73.

LANGER, Ellen. Mindfulness. Boston: Da Capo Press, 1989.

LAZAR, Rina. "The Familiar and the Strange: The Dynamics of Change." The Israel Journal of Psychiatry and Related Sciences, vol. 32 (3), 1995, pp. 157-166.

MIALL, David S.; KUIKEN, Don. "Foregrounding, Defamiliarization, and Affect: Response to Literary Stories." Poetics, vol. 22 (5), 1994, pp. 389-407.

MITCHELL, Stanley. "From Shklovsky to Brecht: Some Preliminary Remarks Toward a History of Politization of Russian Formalism." Screen, vol. 15, 1974, pp. 74-80. 
OATLEY, Keith. "A Taxonomy of the Emotions of Literary Response and a Theory of Identification in Fictional Narrative." Poetics vol. 23 (1-2), 1995, pp. 53-74.

PEER, Willie van. Stylistics and Psychology: Investigations of Foregrounding. London: Croom Helm, 1986.

ROBINSON, Douglas. Estrangement and the Somatics of Literature: Tolstoy, Shklovsky, Brecht. Baltimore: John Hopkins University Press, 2008.

SEMINO, E. 1995. "Schema Theory and the Analysis of Text Worlds in Poetry." Language and Literature, vol. 4 (2), pp. 79108.

SHELLEY, Percy Bysshe. The Selected Poetry and Prose of Shelley. Wordsworth Editions, 1994.

SHKLOVSKY, Viktor. "Art as Technique." In: Russian Formalist Criticism: Four Essays, translated by Lee T. Lemon and Marion J. Reis. Lincoln: University of Nebraska Press, 1965, pp. 3-24.

SHKLOVSKY, Viktor. "Art as Device." Book Section. In: Theory of Prose, translated by Benjamin Sher. Champaign: Dalkey Archive Press, 1991, pp. 1-14.

SHKLOVSKY, Viktor. "A Sentimental Journey." In: Viktor Shklovsky: A Reader, translated by Alexandra Berlina. New York: Bloomsbury Academic, 2016a, pp. 135-152.

SHKLOVSKY, Viktor. "'Art as Device."' In: Viktor Shklovsky: $A$ Reader, translated by Alexandra Berlina. New York: Bloomsbury Academic, 2016b, pp. 73-96.

SHKLOVSKY, Viktor. "On the Theory of Prose (1983)." In: Viktor Shklovsky: A Reader, edited by Alexandra Berlina. New York: Bloomsbury Academic, 2016c, pp. 298-344.

SHKLOVSKY, Viktor. "Tales about Prose." In: Viktor Shklovsky: $A$ Reader, edited by Alexandra Berlina. New York: Bloomsbury Academic, 2016d, pp. 258-274.

SPIEGEL, Simon. "Things Made Strange: On the Concept of 'Estrangement' in Science Fiction Theory." Science Fiction Studies, vol. 35 (3), 2008, pp. 369-85.

STEINER, Genevieve Z, and Robert J Barry. "The Mechanism of Dishabituation." Frontiers in Integrative Neuroscience, vol. 8, 2014, 14pp. 
STERNBERG, Meir. "Epilogue. How (Not) to Advance toward the Narrative Mind." In: Cognitive Poetics: Goals, Gains and Gaps., edited by Geert Brône and Jeroen Vandaele, 2009, pp. 455-532. STERNBERG, Robert. Cognitive Psychology. Boston: Cengage Learning, 2008.

STORBECK, Justin; CLORE, Gerald. "On the Interdependence of Cognition and Emotion." Cognition \& Emotion, vol. 21 (6), 2007, pp. 1212-1237.

STRIEDTER, Jurij. Texte Der Russischen Formalisten I. München: Wilhelm-Finck-Verlag, 1969.

SUVIN, Darko. Metamorphoses of Science Fiction: On the Poetics and History of a Literary Genre. Yale University Press, 1979.

TODOROV, Tzvetan. "Poetic Language: The Russian Formalists." In: Literature and Its Theoretists, edited by Tsvetan Todorov. London: Routledge, 1988, pp. 10-28.

TOLSTOY, Lev. War and Peace. Translated by Louise and Aylmer Maude. 2016. Project Gutenberg. Available at: https://www. gutenberg.org/files/2600/2600-h/2600-h.htm.

VAILE WRIGHT, Caroline; COLLINSWORTH, Linda; FITZGERALD, Louise. "Why Did This Happen to Me? Cognitive Schema Disruption and Posttraumatic Stress Disorder in Victims of Sexual Trauma." Journal of Interpersonal Violence, vol. 25 (10), 2010, pp. 1801-1814.

VARRA, Edward M. et al. "Factor Analysis of the Trauma and Attachment Belief Scale: A Measure of Cognitive Schema Disruption Related to Traumatic Stress." Journal of Psychological Trauma, vol. 7 (3). Taylor \& Francis Group, 2008, pp. 185-196.

VONNEGUT, Kurt. Slaughterhouse-Five or The Children's Crusade: A Duty-Dance with Death. New York: Dell Publishing, 1991.

VONNEGUT, Kurt. Breakfast of Champions. Manhattan: Random House, 2010.

YOUNG, Jeffrey. Cognitive Therapy for Personality Disorders: A Schmema-Focused Approach. Sarasota: Professional Resource Press, 1994.

YOUNG, Jeffrey, Janet Klosko, and Marjorie Weishaar. Sche- 
ma Therapy: A Practitioner's Guide. New York: Guilford Press, 2006.

ZHANG, Ting, et al. "A 'Present' for the Future: The Unexpected Value of Rediscovery." Psychological Science, vol. 25 (10), 2014, pp. 1851-60.

ZUNSHINE, Lisa. Why We Read Fiction: Theory of Mind and the Novel. Columbus: Ohio State University Press, 2006.

Recebido em: 15/04/2020

Aceito em: 19/07/2020

Publicado em setembro de 2020 